\title{
Listening to the Experts
}

\section{Carol Iannone}

In the spring of the year 2020 of the Common Era, science fiction became reality. Or so it seemed. A virus, likely spawned in a laboratory in a Chinese city called Wuhan, had escaped from its confinement and was allowed to spread throughout the world via air and other means of travel. Chinese scientists who tried to raise alarms about the virus, soon to be christened with the futuristic name COVID-19, disappeared from public view. Although it had a high survival rate, and in many cases carried minimal or no symptoms, and only certain segments of the population were truly vulnerable, authorities decided that it was necessary to shut down normal life.

And so, in a manner of speaking, the earth stood still. Schools, libraries, colleges, churches, synagogues, stadiums, restaurants, theatres, cinemas, concert halls, opera houses, and office buildings closed down. Neighborhood stores also closed, except for the few deemed essential to maintaining mere biological existence. Thanksgiving and Christmas were virtually cancelled. Weddings, graduations, funerals, were curtailed, as was travel. Even visits with relatives and gatherings of friends were discouraged, and many dear souls departed mortal life with no loved ones at their side to say farewell.

Certainly, there were deaths and much suffering in some cases, although it wasn't always clear if the stricken had died from the virus or just with the virus and some other difficulty. Exact and solid information was hard to come by, as data and models and directives seemed to shift daily. Having begun in the early spring as a temporary measure to "flatten the curve," that is, to diminish the escalation of new cases, the shutdown gradually consumed the rest of 2020 and then threatened to consume 2021 as well.

Even populous cities were eerily empty and deserted as the invisible virus ruled over silent streets. In time things loosened up a bit and people returned

Carol lannone is editor-at-large of Academic Questions, 12 East 46th Street, 6th Floor, New York, NY 
to the sidewalks and the parks and the partially opened stores, but all were masked, even small children who were the least at risk, and even in the open air. This presented a bizarre spectacle, especially as cold weather arrived and people added caps and hats and fur trimmed hoods to their usually dark and dark patterned designer masks, becoming yet more anonymous and spectral as they lumbered through the frosty air. Frequent handwashing, social distancing, and masks were the recommended measures, and one must avoid touching one's face. By some calculations the virus had yet to be fully isolated, but humans were being isolated from themselves and each other.

It was far from certain that the unprecedently extreme lockdown was really necessary, cutting off the livelihoods of many, destroying small businesses, neighborhood restaurants, and the labor of lifetimes. What had been a thriving economy began to shred, leading to isolation, unemployment, idleness, malaise, depression, drinking, drugging, lack, want, despair, suicide, and a rise in crime. Children were losing months of schooling and the discipline of routine. The cure seemed worse than the disease and was made even worse when government handouts replaced making one's own living.

Officials in their public broadcasts kept invoking "science" for their directives, but science entails reason, argument, evidence, proof, falsifiability. Yet physicians and scientists who objected to the severity of the lockdown and proposed alternative measures and treatments were ignored and suppressed and denied platforms on social media. It was always possible to claim, as did Nicholas Christakis, Sterling Professor of Social and Natural Science at Yale, that without the lockdown millions more might have died, something impossible to verify.

One Nobel scientist asserted that a healthy society quarantines the contagious, protects the vulnerable, and lets everyone else operate freely. It seems the opposite occurred. Bungling bureaucrats insisted healthy people must mask and socially distance, but placed COVID infected patients in nursing homes, precipitating deaths among the especially vulnerable elderly.

And we saw a suspicious flexibility in the face of developing circumstances. Officious government authorities who had volubly laid down strict rules of confinement were caught violating them, having their hair done, eating convivially with friends at tony restaurants, and travelling for various personal reasons. 
Especially egregious was the flexibility illustrated in face of the political turmoil precipitated by the death of a black man, George Floyd, in police custody in May. This disturbing incident eventuated in mass protests with large numbers of people often unmasked and gathered close together. So far from causing alarm, this precipitated servile acquiescence in 1,200 public health and medical professionals who found a way to subordinate the virus to progressive ideology in an open letter in June: "We wanted to present a narrative that prioritizes opposition to racism as vital to the public health," the letter explained in clumsy prose adapted from oppression studies. "We believe that the way forward is not to suppress protests in the name of public health."

A hearty collective laugh at such elastic doublethink might have broken the mesmerism, but it became the model for more of the same regarding even other, more familiar viruses. Cornell University declared that all students must have the flu vaccine or else lose access to campus buildings . . . except for ... students of color-who, it was said, rightly feel distrust of authority.

Almost as bad as the elusive virus itself was the pacific complacency of much of the population in consenting to the numbing of ordinary life and the curtailment of freedom. Already locked down in spirit by decades of belligerent political correctness and the more recent rise of cancel culture, they seemed primed to accept and obey, leading radio talk show host Dennis Prager to remark that he now understood "the good German" under the Nazis, or the average Russian under Stalin, who did no harm but neither raised any protest against the brutality that others perpetrated. But those people faced the gestapo and the gulag if they resisted; Americans were capitulating before Ibram X. Kendi and Dr. Fauci. Nevertheless, “wokeness” could exact punishment enough relative to our context, as we have repeatedly seen, and casual disagreement with the shutdown could surprisingly arouse snarling denunciations and withering accusations even from those one had thought were friends.

So many elements of our civilization had already been corrupted, politicized, weaponized, radicalized, racialized-art, literature, science, media, government, language itself-that there weren't enough tools to mount an effective resistance, either to the shutdown, or to the riots, looting, arson, and monument toppling that regularly followed the protests.

All in all, one lesson to learn from the year 2020 of the Common Era should be to exercise vigorous skepticism toward expert opinion. The special feature for this issue builds that skepticism into a pointed question, "The Experts 
Speak?" Our authors provide some answers to that question in articles on a wide variety of topics. They challenge the "expert" distortions arising from:

- the relatively new field of History of Science (John Staddon, "History of Science: Politicizing a Discipline”)

-affirmative action (Carl Cohen, “What is Affirmative Action?”)

- the effect of mass immigration on the pocketbook (Steven A. Camarata, “Immigration 'Experts' vs. Wages”)

-the unprofessional armchair diagnoses of President Trump's mental health (Bruce Gilley, “The Minjung Millenarianism of Bandy X. Lee”)

-the ongoing perversity of "diversity" (Mark Zunac, "Whiteness and the Great Lie of Diversity”)

- economists' profound miscalculations in sending aid to the undeveloped world (Anthony Daniels, “Economic Development: The Dismal Science”)

-fatuous Western idealization of dictators (Daniel Pipes, “Getting Bashar al-Assad Very Wrong”)

-ignorantly confident assurances about the effects of mass immigration (Jason Richwine, “The 1965 Immigration Act: A Little Humility, Please”)

-the professoriate's fatally bungled handling of the humanities (Mark Bauerlein, “The Few, the Proud, the Profs”)

-false alarm about the size of the prison population (Barry Latzer, "The Mass Incarceration Bogeyman”)

-overly assured pronouncements about the nature of art (Michelle Marder Kamhi, “Beware the Semmelweis Reflex”) 
- unwarranted certainty about the nature of matter itself (Joel Brind,

“The Parable of the Juggler”)

In Articles, the damage "diversity" has done to education, culture, and the country in general is enormous, but perhaps there is still room for some dark humor (Noah Carl, "More Diversity? Talk is Cheap”), while Matthew Stewart soberly reviews Diversity Rules by Peter W. Wood and On Diversity: The Eclipse of the Individual in a Global Era by Russell Jacoby.

Glynn Custred's sweeping survey, “From Bologna to Zoom: The Evolution of the University,” broadly explains the development of the university from its beginnings to its intellectually threadbare state today. In "Citations and Gamed Metrics: Academic Integrity Lost," Jaime A. Teixeira da Silva exposes the corrupted system of academic status striving and desperate citations tallying.

"Poverty and Culture," in which Lawrence M. Mead explains the thesis of his recent book, Burdens of Freedom: Cultural Difference and American Power, was, lamentably, cancelled by Society magazine in response to PC objections. We publish it here in our "For the Record" category.

In reviews, Glynn Custred appreciates Mark Levin's Unfreedom of the Press; Gorman Beauchamp elaborates Robert Boyers's intentions in The Tyranny of Virtue: Identity, the Academy, and the Hunt for Political Heresies; Sidney M. Milkis takes issue with the Claremont school as he considers Bradley C.S. Watson's Progressivism: The Strange Career of a Radical Idea; Robert L. Paquette lauds Bernard Bailyn's Illuminating History: A Retrospective of Seven Decades; and Michael Walsh questions Cynical Theories: How Activist Scholarship Made Everything about Race, Gender, and Identity-and Why This Harms Everybody by Helen Pluckrose and James A. Lindsay

A generous selection of beautifully constructed poems by Catharine Savage Brosman finishes up the issue. 